DOI: 10.20287/ec.n27.v2.a05

\title{
From narrative machines to practice-based research: making the case for a digital Renaissance
}

\author{
Paulo Nuno Vicente \\ Universidade Nova de Lisboa, iNOVA Media Lab \\ E-mail: inovamedialabefcsh.unl.pt
}

\begin{abstract}
Contemporary communication sciences are embedded with theoretical traditions supportive of an occupational boundary work: the social and the cultural world as a strict sociological and anthropological object of study and the material world as the domain of scientists and engineers. This epistemic divide places communication sciences before a future shock, by failing to respond explicitly to emerging mediations made possible by radical technolo-

represented in communication studies and has yet to be further articulated in order to provide a clear epistemological foundation. This paper objective is to fill in that knowledge gap: it positions digital media as a transdisciplinary scientific domain with a triple helix structure (hardware, interface, and software studies), placing $\mathrm{PbR}$ as a critical native methodological approach and presenting a holistic research framework.
\end{abstract} gies. Practice-based research $(\mathrm{PbR})$ is still under-

Keywords: digital media; embodied mind paradigm; narrative machines; practice-based research; transdisciplinarity.

CINCE the evolving relations between computers, digital interfaces, and on-line networks entered the spheres of human expression and communication, various umbrella nomenclatures were advanced as an attempt to situate and legitimize particular scopes of practice and academic research. Whether taken as a field, a discipline or an interdiscipline, the catalog of designations span from Internet studies, multimedia, cyberculture, digital culture, new media, interactive media, computer-mediated communication, human-computer interaction, software studies, cultural computing, and a full range of cyber and $e$ - subsidiaries linked to the particularities of disciplinary, occupational and thematic settings (e.g. cyberpsychology, cyberjournalism, e-learning, e-health).

Particular ontological considerations (what digital media is) have given rise to specific epistemologies (what and how can we know about digital media) and the research project, rather than the domain, has been the privileged site for interdisciplinarity. Academic departments were institutionalized, study programs and courses were created, and scientific journals published. Theoretical

Data de submissão: 2018-03-12. Data de aprovação: 2018-09-24.

A Revista Estudos em Comunicação é financiada por Fundos FEDER através do Programa Operacional Factores de Competitividade - COMPETE e por Fundos Nacionais através da FCT - Fundação para a Ciência e a Tecnologia no âmbito do projeto Comunicação, Filosofia e Humanidades (LabCom.IFP) UID/CCI/00661/2013.

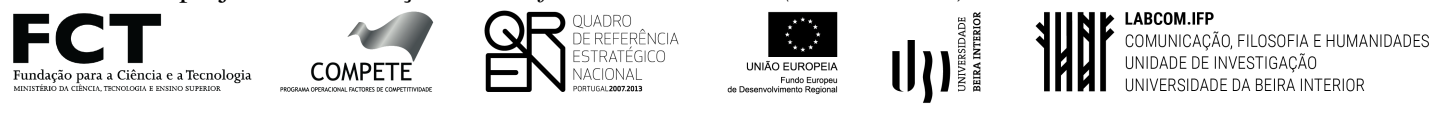


models were conceived, methodological tools developed and practical applications produced, addressing the vast gamut of social and cultural phenomena connected with the use of computers, the Internet and virtual worlds in communication, but often to establish these as "new terrains for old methods" and "quarantine the novelty of electronic media" (Venturini \& Latour, 2009, pp. 89-90).

Subject fragmentation has been the tacit condition for knowledge formation in digital media research: we are able to collect and address the fragments, but there are still epistemic fractures, and these hinder a better reflection on the subject's nature and the implied phenomena. In this paper we take into account how the fissures at the ontological level constrain knowledge domain navigation and argue that current intellectual conditions in communication sciences affect explicit knowledge creation. The main question we address is: how can communication sciences remain relevant to contemporary societies in the face of emerging radical technologies and the mediations they enhance?

First, at the societal level, this question is justified because of the progressive network integration of radical technologies such as the smartphones, the Internet of Things, augmented and virtual reality, automation, machine learning and artificial intelligence, 3D printing, and cryptocurrency lean our everyday life towards connected objects, the augmentation of perception, and machinic discretion (Greenfield, 2018): the social fabric is being rewired, at the individual and at the institutional level, by complex technological systems which resemble black boxes, still considerably unaccountable both at the technical and infrastructural levels and at the communicational level (e.g. Ananny \& Crawford, 2016; Diakopoulos, 2016).

Second, at the scientific and academic levels, because communication sciences are lagging behind in the study and teaching of the complex and largely opaque emerging mediations to which, in this paper, we call narrative machines, encompassing all forms of human-computer communication, particularly algorithmic, that are already and will be (de)materialized using those same technologies. Our premise is that communication sciences are on the verge of a future shock, one that "occurs when you are confronted by the fact that the world you were educated to believe in doesn't exist" (Postman \& Weingartner, 1969, p. 14): communication sciences need to be reexamined and expanded in the light of the contemporary communicational ecology and actively engage, in a forensic way, with the algorithmic turn, its grammars and structures.

Third, at the epistemic level, because former theoretical and disciplinary stances towards digital media started developing their own metatheories and metaconcepts, very often making these same constructs the topic of discourse, and very soon generating the need for message decryption across disciplines. To operationalize a link between biological, technological, social and cultural aspects of communication is still an exception and very often a matter of academic occupational boundary and contest (Bondebjerg, 2017).

If a digital nature (ontology) is to be recognized, that own nature shall be included in digital media knowledge (epistemology). In other words: if numerical representation changes the nature of media (Manovich, 2001) making volatile signs (Ryan, 2004) the raw material for intrinsically procedural environments in which the computer is fundamentally an engine (Murray, 1997), the current disciplinary digital divide is unsustainable between computer science, communication studies, arts, design, humanities and the social sciences. 
In any case, a word of caution: this is not to say that legacy communication theories, as epistemologies, are to be disregarded by digital media scholars, nor that their academic legacy is undermined and reached the limits of their own contribution. Rather, it is to state that their seminal frameworks need to be expanded into a much more transdisciplinary perspective, but that this socio-technological expansion is still very scarcely recognized and applied within social and human sciences (e.g. Giglietto \& Rossi, 2012; Hendler, Shadbolt, Hall, Berners-Lee, \& Weitzer, 2008; Tress, Tress, Décamps, \& d'Hauteserre, 2001).

\section{The rise of narrative machines}

The current ecosystem of smartspeakers, smart TVs and their computational assistants (Alexa, Cortana, Google Assistant, Siri), offers a glimpse into the world of emerging radical technologies and the increasing invisibility of mediation. At the moment, artificial intelligence speakers already allow for non-linear aural storytelling skills (e.g. Select a Story, Amazon Alexa). In a fictional narrative world of princes, fairies and dragons, the user gets to select the main character and the associated point of view, the story paths and ending, using voice as a command.

However, considering the ongoing developments in the personalization of artificial intelligence (e.g. Yang et al., 2018; Zhou, Huang, Hu, Zhu, \& Tang, 2018), it is not far from sight the time when Alexa, Siri, Cortana and all the virtual assistants to come will actually have an holographic body, configurable artificial personality, learning from our own biometric data collected by wearable sensors and shared by Wi-Fi: the official soundtrack for our fictional and non-fictional stories automated from our Spotify profile, story world environments textured from our Instagram and YouTube accounts, heroes and villains profiled, plot points and narrative arcs structured from our Facebook and Twitter friends, and the story artifacts related to our on-line shopping environments.

While these are prospective renderings, here brought as an illustration, for a matter of relevance in the contemporary world, digital media research needs scenario planning (Rowland \& Spaniol, 2017) since, more than a conditional statement, IFTTT (If This Than That) is becoming the aphorism of an Era where computer power finds biological knowledge and anthropomorphic interfaces (Harari, 2017).

Although human communication is naturally multimodal, integrating speech, gesture, movement of the body, digital media neomaterialities establish renewed and emergent conditions, structures and grammars for the mediated expression and communication (syntactic, aural, visual, kinetic and haptic both in 2D and in 3D environments), making clear how relevant it is to conceptualize the multimodal signal both as the "physical properties in terms of the channel through which it is sent" as "the receiver sensory systems used to detect it" (Higham \& Hebets, 2013).

Currently, sonification algorithms are already used to help identify mutations in repetitive DNA sequences that are obscure by visual inspection (Temple, 2017): besides being seen (e.g. Goodstadt \& Marti-Renom, 2017), DNA structures can now "tell a story" through musical instrument digital interface (MIDI) and be listened for scientific analysis. Similar examples of transdisciplinary collaboration as aesthetic experience and scientific inquiry can be found regarding texture, art and deep neural networks (Gatys, Ecker, \& Bethge, 2017), the sonification of proteins (Dunn \& Clark, 2006), ice core, radar, seismic and solar wind data (Quinn \& Meeker, 2001), and alre- 
ady translate at the consumer electronics' level in smartphone apps like Prisma, Artisto, Deep Art Turbo, which use image processing algorithms based on neural networks.

The socio-technical complexity and opacity of radical technologies, such as machine learning, as well as the global interdependence of contemporary societal challenges, are thus in stringent contrast with monodisciplinary communication sciences' theoretical frameworks, the required digital skills traditionally absent from social scientists' technical training, and with the overall disciplinary organization of university departments.
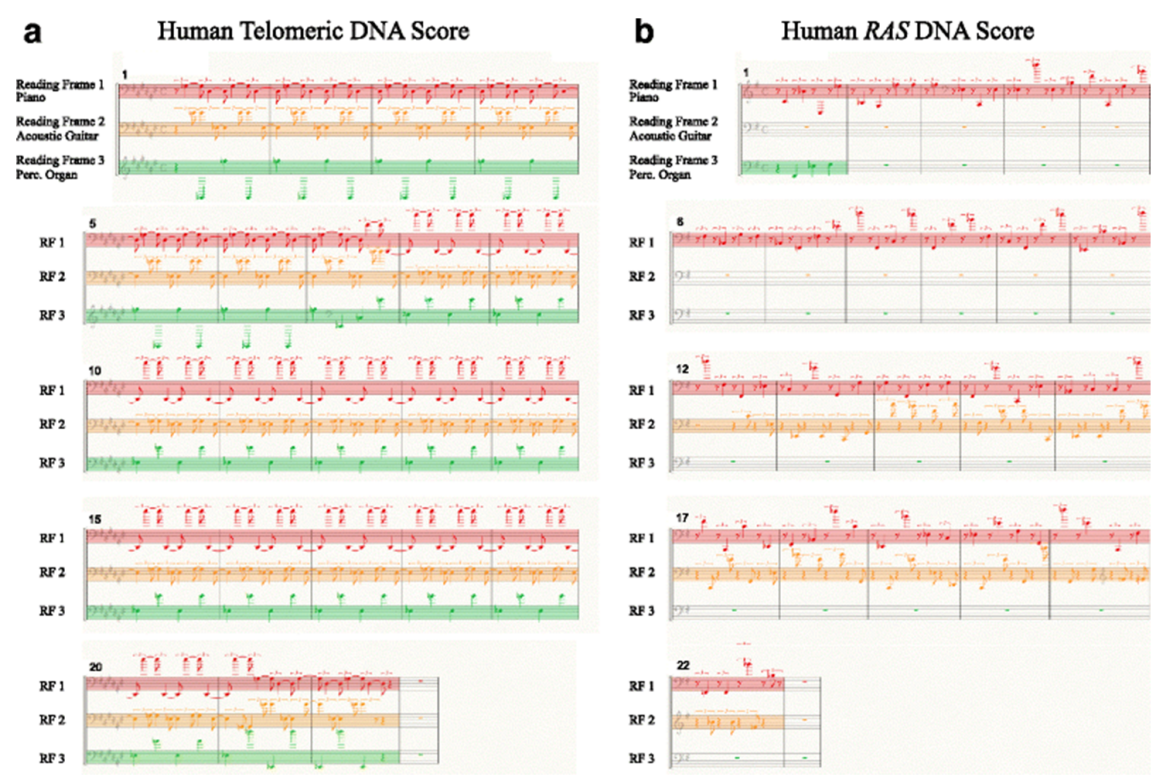

Figure 1. Musical score representation of DNA (Temple, 2017)

\section{The triple helix of digital media and practice-based research}

The articulation of technology, symbolic codes, particular social and cultural settings, economic and political contexts is what makes a medium (Postman, 1985). Therefore, a medium is the entanglement of systems (macro level), organizations (meso level), the individuals and their agency (micro level). We sustain that the multilayered nature and phenomena of digital media can only be properly addressed by a higher level of integration among fields and disciplines, working together to develop new theories, concepts, methods and applications around common problems. To this process towards transdisciplinarity we call a digital Renaissance.

For this articulation to be fully realized, a thick description of digital media as an expressive and communicative procedural instance is needed: both a procedural instance of (1) media design, (2) media creation and (3) media user experience. From the epistemic angle, this equals saying: 
Digital researchers don't study media; they study in media ${ }^{1}$. As such, the locus of digital media research has a triple helix structure - hardware, interface, and software - and that (i)materiality needs to be made visible through a know how/know why methodological approach.

Hardware, interface, and software are cultural and social artifacts themselves just as they are the media technologies that allow for a plethora of other digital artifacts to be created and disseminated. Hardware, interface, and software are social and cultural actions. So, the contact with the system structures that make digital media realities is a fundamental requirement to a simultaneously in and out meaning-making. Studying within digital media the workings of the world, native digital researchers are expected to organically get their hands on computational systems (e.g. Ippolito, Blais, Smith, Evans, \& Stormer, 2009).

The entanglement of digital media triple helix structure and multimodal communication challenges the legacy notion through which humans stand as the audience in relation to a narrative performance. Instead, expression and communication become active embodied experiences, more than an aesthetic event or work, with different sensible configurations (Elo \& Luoto, 2014). This requires a paradigm shift in communication studies, as it stresses a need for theorist-practitioners that has been previously voiced, stating how many academics in social sciences and humanities still doesn't grasp how computers, software, and interfaces are the contemporary media for human creativity (e.g. Hookway, 2014; Manovich, 2013; Wardrip-Fruin \& Harrigan, 2004).

\section{Table 1. Digital media triple helix research framework (HIS)}

\begin{tabular}{|c|c|c|}
\hline Digital media research locus & Procedural instance & Representational attributes in $2 \mathrm{D}$ and $3 \mathrm{D}$ \\
\hline Hardware studies & & Syntactic \\
\hline & Media design & Aural \\
\hline Interface studies & Media creation & Visual \\
\hline Software studies & Media user experience & $\begin{array}{l}\text { Kinetic } \\
\text { Haptic }\end{array}$ \\
\hline
\end{tabular}

These neomaterialities and their inherent representational attributes are changing our relationship with the media, our representation as subjects, and restructuring culture and communication (Paul, 2015), requiring renewed modes of engagement from researchers. The epistemic divide between theory and practice in conventional communication studies disregards that practice-based research $(\mathrm{PbR})$ is founded on a co-evolutionary premise "where the existing technology is used in a new way and from which technology research derives new answers: in turn, the use of new digital technology may lead to transformation of existing forms and traditional practices" (Edmonds et al., 2005, p. 458).

While practice generates the relevant artifacts and phenomena, scientific research grants its systematic investigation. Thus, "not only is practice embedded in the research process but research questions arise from the process of practice, the answers to which are directed towards enlightening and enhancing practice" (Candy \& Edmonds, 2018, p. 63).

1. Remixed from Clifford Geertz' essay Thick description: Toward an interpretive theory of culture: “The locus of study is not the object of study. Anthropologists don't study villages (tribes, towns, neighborhoods...); they study in villages. (...) social actions are comments on more than themselves" (Geertz, 1973, p. 22). 
As PbR is still under-represented in communication studies, it is relevant to make clear that, while interdependent, practice does not equals research. As a scientific method, $\mathrm{PbR}$ demands that researchers "develop theoretical frameworks that inform and guide the making and evaluation of the outcomes of their practice" (Edmonds \& Candy, 2010, p. 470), i.e. for the research process it is central and unavoidable both the theoretical and conceptual constructs and working from within digital media to test and advance ideas.

This theorist-practitioner model and $\mathrm{PbR}$ find a resemblance with the Renaissance polymath genuine interest and craftsmanship in sciences, engineering and the arts and Renaissance studios translate into the contemporary media labs as native cultural settings for the transdisciplinary think-demo-publish iteration in research, as well as for the development of appropriate methods to address the domain specific subjects (e.g. Marres \& Gerlitz, 2016; Rogers, 2013; Venturini, Munk, \& Meunier, 2016).

\section{The emerging science of narrative}

If one is willing to understand what communication sciences, as a scientific domain, are and need to be in the face of radical technologies, one shall look at what practitioners do, where they do it, how they do it. The acknowledgement of creative studios as research laboratories challenges the boundary work of disciplines and academic departments, as it does the transdisciplinary link between biological, technological, social and cultural aspects of communication.

Evidence from cognitive neuroscience suggests that not only does the brain has a narrative basis - a regionally distributed neural network in the human central nervous system - as the ability for storytelling is responsible for structuring memory. Several states of dysnarrativia, i.e. states of narrative impairment, have been reported and a relationship has been established between particular clinical manifestations (arrested narration, unbounded narration, undernarration, denarration) and neuroanatomic substrates, highlighting why, at the brain level, narrative is the fundamental process of organizing human experience: storytelling simultaneously prompts memory production and the (re)arranging of events into a state of coherence, consecution, and consequence (Marini, Zettin, \& Galetto, 2014; Young \& Saver, 2001).

In other words, the process of (re)creating and (re)telling stories (re)creates the memories' (re)structuring. This is also what cognitive psychologists have termed, at the mind level, as the narrative construction of reality (Bruner, 1991). Thus, narrative organizes human experience at the brain level and it is the mental process through which we (re)construct the notion of reality. More recently, behavioral effects have been associated with a neurochemical release (oxytocin) in the brain triggered by emotionally engaging video narratives. Not only that but suggesting postnarrative actions, i.e. the power to affect attitudes, beliefs, and behaviors (Barraza \& Zak, 2009; Lin, Grewal, Morin, Johnson, \& Zak, 2013). Narratives can then be regarded as "neural firing and wiring as a product of enculturation" (Hutto \& Kirchhoff, 2015).

Even though it was only in the late 1980s that the concept of an embodied mind began to have an operative effect on empirical research, its philosophical genesis is already found in the phenomenology of Husserl, Maurice Merleau-Ponty, and Martin Heidegger. The proposition of an embodied cognition challenges the Cartesian premise of a disembodied mind, i.e. the rigid sepa- 
ration between body and mind, reason and emotion. In the opposite direction, modern embodied cognitive science signals "the significant causal or the significant physically constitutive role of the body in cognitive processing" (Wilson \& Foglia, 2017).

Seminal contributions came from the study of metaphor in everyday meaning-making, suggesting that non-literal language is not an adornment or a merely entertaining device of human expression and communication, but reflects how a domain (e.g. love) is cognitively structured and how this structuring is actively informed by our physicality, moving the study of language beyond the traditional boundaries of conventional linguistics (Lakoff \& Johnson, 1980).

With metaphor giving meaning to form and be conceptualized in terms of time and space, a natural research move went into moving metaphors and how these work as schemas in audiovisual and cinematic communication, i.e. how a set of linked mental representations of the world translate into space-time appropriation that is more complex than simple continuity (e.g. Bordwell, 1985, 1989; Isenhour, 1975; Pearlman, 2017).

As a response to the psychoanalytic-semiotic theoretical paradigm, these works established the research tradition of cognitive film theory, now a driving force in the bigger sphere of cognitive media theory (Nannicelli \& Taberham, 2014). The inquiry on how human experience and interpret audiovisual and narrative structures in cinema and other visual media put the embodied mind paradigm into operation and can be traced back to the earlier concept of enactive cognition advanced by Varela, Thompson and Rosh (1991). Here the seminal idea is that our experiences are constructed through the interaction of mind-body-world, i.e. the creative mind as an articulation between cognition, society and culture, an idea that was further expanded towards artificial intelligence and robotics (e.g. Clark, 1996; Minsky, 1985).

\section{Contribution: an holistic framework for digital media and embodied narratives}

In this paper, we have sought to demonstrate how digital media research legacy has at its foundations a considerable subject fragmentation. This kaleidoscopic pulverization is not only due to the polymorphic nature of its artifacts and phenomena, to the coexistence of different disciplinary domestications, particular schools of thought and theoretical traditions in communication studies, but more precisely to how these defined what the subject is - its ontology - extracting specific moratoria with an impact on their epistemological frameworks: for instance, in explorations strongly embedded with the constructivist paradigm and cultural studies - two of the most important legacies in social and human sciences - the digital nature of the subject is still often left out or, at a minimum, disconnected from its technological realities and intricacies.

Even if often necessary and advisable for a convenient administrative division of scientific work, the theory-practice antinomy, as an ethos in digital media research, is remarkably limited to comprehensively address the complexity of contemporary radical technologies and their emerging mediation regimes. In this regard, we propose (1) a native scientific setting - digital media laboratories as studios - conceived as trading zones for boundary communication processes and artifacts, (2) an intrinsic methodology for theorist-practitioners - practice-based research as the interdependence of critical intellectual work (thick descriptions) and technological knowledge - 
and (3) a holistic framework able to articulate and operationalize research in digital media as a transdisciplinary domain with a triple helix structure:

Table 2. HIS research framework adapting and expanding Edmonds and Candy (2010)

\begin{tabular}{|c|c|c|c|c|c|c|}
\hline $\begin{array}{l}\text { Digital } \\
\text { media } \\
\text { research } \\
\text { locus }\end{array}$ & $\begin{array}{c}\text { Procedural } \\
\text { instance }\end{array}$ & $\begin{array}{c}\text { Representational } \\
\text { attributes } \\
\text { in } 2 \mathrm{D} \text { and } 3 \mathrm{D}\end{array}$ & Elements & Activities & Outcomes & $\begin{array}{c}\text { Operative } \\
\text { verb }\end{array}$ \\
\hline $\begin{array}{c}\text { Hardware } \\
\text { studies }\end{array}$ & & & Practice & $\begin{array}{l}\text { Create } \\
\text { Program } \\
\text { Exhibit }\end{array}$ & Works & Demonstrate \\
\hline $\begin{array}{c}\text { Interface } \\
\text { studies }\end{array}$ & $\begin{array}{l}\text { Media design } \\
\text { Media creation } \\
\text { Media user } \\
\text { experience }\end{array}$ & $\begin{array}{c}\text { Syntactic } \\
\text { Aural } \\
\text { Visual } \\
\text { Kinetic } \\
\text { Haptic }\end{array}$ & Theory & $\begin{array}{l}\text { Read } \\
\text { Think } \\
\text { Write }\end{array}$ & Frameworks & Think \\
\hline $\begin{array}{c}\text { Software } \\
\text { studies }\end{array}$ & & & Evaluation & $\begin{array}{l}\text { Observe } \\
\text { Record } \\
\text { Measure } \\
\text { Analyze }\end{array}$ & Evaluations & Report \\
\hline
\end{tabular}

HIS research framework seeks to integrate the "reflexive conversation with the materials of the design situation" (Dahl, 2016, p. 76), as well a necessary holistic vision for practice, theory and evaluation across the different but symbiotic digital media locus, activities, outcomes, and operative verbs, pursuing to complement previous seminal work at the level of PbR research life cycles (Edmonds et al., 2005) and its trajectories' mapping (Edmonds \& Candy, 2010).

With this proposal we aim to establish a clear and articulated foundation, both at the ontolological and at the epistemological levels, for further inquiries in the transdisciplinary domain of digital media, interconnecting its neomaterialities and including a scenario planning for contemporary algorithmic mediation and embodied narratives.

Findings from cognitive science make clear the need for a transdisciplinary endeavor in digital narrative studies able to bring to light the social brain, one that is changed when in contact with the representational attributes of the media and the arts. Digital media representational attributes open the possibilities for new multimodal signals in fictional and non-fictional narrative worlds. As such, HIS research framework foresees an emerging research agenda in cognitive digital media studies, entailing the connection between (1) digital story structures, (2) multimodal metaphors and (3) mediated cognition structures: 
Table 3. Emerging cognitive digital media studies research agenda

\begin{tabular}{|c|c|c|}
\hline Research topic & Objective & Exemplary research questions \\
\hline $\begin{array}{l}\text { Digital story } \\
\text { structures }\end{array}$ & $\begin{array}{l}\text { To develop a taxonomy of } \\
\text { contemporary digital narrativity }\end{array}$ & $\begin{array}{l}\text { What relationships exist between } \\
\text { storytelling archetypes and } \\
\text { conventions and digital media } \\
\text { affordances? } \\
\text { Are the invisible/immaterial } \\
\text { contemporary narrative containers } \\
\text { (e.g. algorithms) generating new } \\
\text { storytelling structures? }\end{array}$ \\
\hline $\begin{array}{l}\text { Multimodal } \\
\text { metaphors }\end{array}$ & $\begin{array}{l}\text { To elicit how digital media } \\
\text { representational attributes inform the } \\
\text { creation of multimodal metaphors }\end{array}$ & $\begin{array}{c}\text { How does multimodal non-literal } \\
\text { language structures human domains? }\end{array}$ \\
\hline $\begin{array}{l}\text { Mediated } \\
\text { cognition } \\
\text { structures }\end{array}$ & $\begin{array}{c}\text { To map the relations between cognitive } \\
\text { processes and multimodal narrative } \\
\text { structures }\end{array}$ & $\begin{array}{l}\text { Do particular narrative structures and } \\
\text { multimodal metaphors across } \\
\text { particular digital media organize the } \\
\text { structure of human experience and } \\
\text { cognition differently? }\end{array}$ \\
\hline
\end{tabular}

HIS research model frames story structures as the organizational properties of a coherent narrative, organizing in a communicatively way the workings of the world. If mediation can be conceived as cognition, and thus media as cognitive instances, then, we propose, cognitive media theory needs to expand empirically towards digital media cognitive studies, including the now multimodal metaphors we live by. In the light of advances in cognitive sciences, the embodied mind paradigm requires a transdisciplinary approach in the study of human phenomena, putting previously disconnected disciplines to address complex problems.

An emerging science of narrative can now address stories and its structures as the result of a dynamic interplay between brain structures, the mind-body at work, the social and the cultural as lived experiences, and the technological basis of communication. For this research shift to be consolidated universities and research centers are called to embrace a digital Renaissance that fosters frontier intellectuals - digital humanists as theorist-practitioners - if more than programmed by external powers (political, economic, technological) they aspire to program the future of a human-centered communication.

\section{References}

Ananny, M. \& Crawford, K. (2016). Seeing without knowing: Limitations of the transparency ideal and its application to algorithmic accountability. New Media \& Society, 20(3): 973989. DOI: $10.1177 / 1461444816676645$

Barraza, J. A. \& Zak, P. J. (2009). Empathy toward strangers triggers oxytocin release and subsequent generosity. Annals of the New York Academy of Sciences, 1167: 182-189. 
Bondebjerg, I. (2017). The creative mind: cognition, society and culture. Palgrave Communications, 3(1): 19. DOI: 10.1057/s41599-017-0024-1

Bordwell, D. (1985). Narration in the fiction film. Madison: University of Wisconsin Press.

Bordwell, D. (1989). Making Meaning: Inference and Rhetoric in the Interpretation of Cinema. Cambridge Massachussets: Harvard University Press.

Bruner, J. (1991). The narrative construction of reality. Critical Inquiry, 18(1): 1-22.

Candy, L. \& Edmonds, E. (2018). Practice-Based Research in the Creative Arts: Foundations and Futures from the Front Line. Leonardo, 51(1): 63-69. DOI: 10.1162/LEON_a_01471

Clark, A. (1996). Being There: Putting Brain, Body, and World Together Again. Cambridge, Massachussets: MIT Press.

Dahl, L. (2016). Designing New Musical Interfaces as Research: What's the Problem?. Leonardo, 49(1): 76-77. DOI: 10.1162/LEON_a_01118

Diakopoulos, N. (2016). Accountability in algorithmic decision making. Communications of the ACM, 59(2): 56-62. DOI: $10.1145 / 2844110$

Dunn, J. \& Clark, M. A. (2006). Life Music: The Sonification of Proteins. Leonardo, 32(1): 25-32. DOI: $10.1162 / 002409499552966$

Edmonds, E. \& Candy, L. (2010). Relating Theory, Practice and Evaluation in Practitioner Research. Leonardo, 43(5): 470-476. DOI: 10.1162/LEON_a_00040

Edmonds, E.; Weakley, A.; Candy, L.; Fell, M.; Knott, R. \& Pauletto, S. (2005). The studio as laboratory: Combining creative practice and digital technology research. International Journal of Human-Computer Studies, 63(4-5): 452-481. DOI: 10.1016/j.ijhcs.2005.04.012

Elo, M. \& Luoto, M. (eds.). (2014). Senses of Embodiment: Art, Technics, Media. Bern: Peter Lang.

Gatys, L. A.; Ecker, A. S. \& Bethge, M. (2017). Texture and art with deep neural networks. Current Opinion in Neurobiology, 46: 178-186. DOI: 10.1016/j.conb.2017.08.019

Geertz, C. (1973). The Interpretation of Cultures: Selected Essays. New York: Basic Books, Inc., Publishers.

Giglietto, F. \& Rossi, L. (2012). Ethics and Interdisciplinarity in Computational Social Science. Methodological Innovations, 7(1): 25-36. DOI: 10.4256/mio.2012.003

Goodstadt, M. \& Marti-Renom, M. A. (2017). Challenges for visualizing three-dimensional data in genomic browsers. FEBS Letters, 591(17): 2505-2519. DOI: 10.1002/1873-3468.12778

Greenfield, A. (2018). Radical technologies: the design of everyday life. London, New York: Verso.

Harari, Y. N. (2017). Homo Deus: a brief history of tomorrow. London: Vintage.

Hendler, J.; Shadbolt, N.; Hall, W.; Berners-Lee, T. \& Weitzer, D. (2008). Web science: an interdisciplinary approach to understanding the web. Communications of the ACM - Web Science, 51(7): 60-69. DOI: 10.1145/1364782.1364798 
Higham, J. \& Hebets, E. A. (2013). An introduction to multimodal communication. Behav Ecol Sociobiol, 63: 1381-1388. DOI: 10.1007/s00265-013-1590-x

Hookway, B. (2014). Interface. Cambridge, Massachussets: The MIT Press.

Hutto, D. D. \& Kirchhoff, M. D. (2015). Looking beyond the brain: Social neuroscience meets narrative practice. Cognitive Systems Research, 34-35: 5-17. DOI: 10.1016/j.cogsys.2015.07. 001

Ippolito, J.; Blais, J.; Smith, O. F.; Evans, S. \& Stormer, N. (2009). New criteria for new media. Leonardo, 42(1): 71-75. DOI: 10.1162/leon.2009.42.1.71

Isenhour, J. P. (1975). The Effects of Context and Order in Film Editing. AV Communication Review, 23(1): 69-80.

Lakoff, G. \& Johnson, M. (1980). Metaphors we live by. Chicago: The University of Chicago Press.

Lin, P.-Y.; Grewal, N. S.; Morin, C.; Johnson, W. D. \& Zak, P. J. (2013). Oxytocin increases the influence of public service advertisements. PLOS One, 8(2). DOI: 10.1371/journal.pone. 0056934

Manovich, L. (2001). The Language of New Media. Cambridge: The MIT Press.

Manovich, L. (2013). Software takes command. New York: Bloomsburry.

Marini, A.; Zettin, M. \& Galetto, V. (2014). Cognitive correlates of narrative impairment in moderate traumatic brain injury. Neuropsychologia, 64: 282-288. DOI: $10.1016 /$ j.neuropsychologi a.2014.09.042

Marres, N. \& Gerlitz, C. (2016). Interface Methods: Renegotiating Relations between Digital Social Research, STS and Sociology. The Sociological Review, 64(1): 21-46. DOI: 10.1111/1467-954X.12314

Minsky, M. (1985). The society of mind. New York: Touchstone Books.

Murray, J. H. (1997). Hamlet on the Holodeck: The future of narrative in cyberspace. Cambridge, Massachussets: The MIT Press.

Nannicelli, T. \& Taberham, P. (eds.). (2014). Cognitive media theory. New York: Routledge.

Paul, C. (2015). From Immateriality to Neomateriality: Art and the Conditions of Digital Materiality. Paper presented at the ISEA - International Symposium on Electronic Arts 2015, Vancouver.

Pearlman, K. (2017). Editing and Cognition Beyond Continuity. Projections, 11(2): 67-86.

Postman, N. (1985). Amusing ourselves to death: Public discourse in the age of show business. New York: Penguin Books.

Postman, N. \& Weingartner, C. (1969). Teaching as a Subversive Activity. New York: Dell Publishing.

Quinn, M. \& Meeker, L. D. (2001). Research set to music: the climate symphony and other sonifications of ice core, radar, DNA, seismic and solar wind data. Paper presented at the 2001 International Conference on Auditory Display, Espoo, Finland. 
Rogers, R. (2013). Digital methods. Cambridge, Massachussets: The MIT Press.

Rowland, N. J. \& Spaniol, M. J. (2017). Social foundation of scenario planning. Technological Forecasting and Social Change, 124: 6-15. DOI: 10.1016/j.techfore.2017.02.013

Ryan, M.-L. (2004). Will new media produce new narratives?. In M.-L. Ryan (ed.), Narrative across media: the languages of storytelling. Lincoln and London: University of Nebraska Press.

Temple, M. D. (2017). An auditory display tool for DNA sequence analysis. BMC Bioinformatics, 18(221). DOI: $10.1186 / \mathrm{s} 12859-017-1632-\mathrm{x}$

Tress, B.; Tress, G.; Décamps, H. \& d'Hauteserre, A.-M. (2001). Bridging human and natural sciences in landscape research. Landscape and Urban Planning, 57(3-4): 137-141. DOI: 10.1016/S0169-2046(01)00199-2

Varela, F. J.; Thompson, E. \& Rosch, E. (1991). The embodied mind: cognitive science and human experience. Cambridge, MA: MIT Press.

Venturini, T. \& Latour, B. (2009). The Social Fabric: Digital footprints and quali-quantitative methods. Paper presented at the Proceedings of Futur en Seine - The Digital Future of the City.

Venturini, T.; Munk, A. \& Meunier, A. (2016). Data-Sprints: a public approach to digital research. In C. Lury, P. Clough, M. Michael, R. Fensham, S. Lammes, A. Last \& E. Uprichard (eds.), Interdisciplinary Research Methods (forthcoming).

Wardrip-Fruin, N. \& Harrigan, P. (eds.) (2004). First Person. Cambridde, Massachussets: The mit Press.

Wilson, R. A. \& Foglia, L. (2017). Embodied Cognition. In E. N. Zalta (ed.), The Stanford Encyclopedia of Philosophy (Spring 2017 Edition). Metaphysics Research Lab, Stanford University.

Yang, M.; Wenting, T.; Qu, Q.; Zhao, Z.; Chen, X. \& Zhu, J. (2018). Personalized response generation by Dual-learning based domain adaptation. Neural Networks, 103: 72-82. DOI: 10.1016/j.neunet.2018.03.009

Young, K. \& Saver, J. L. (2001). The neurology of narrative. SubStance, 30(94/95): 72-84.

Zhou, Y.; Huang, C.; Hu, Q.; Zhu, J. \& Tang, Y. (2018). Personalized learning full-path recommendation model based on LSTM neural networks. Information Sciences, 444: 135-152. DOI: 10.1016/j.ins.2018.02.053 